\title{
On Improvement of the Off-campus Tutor System for Law Postgraduates
}

\author{
Ying LI \\ Capital University of Economics and Business, Beijing, China \\ 441586900@qq.com
}

Keywords: Law, Postgraduate, Off-campus tutor, Practical ability.

\begin{abstract}
Law postgraduate programs should properly integrate theoretical teaching with practice. The off-campus tutorial system has become an effective path to develop law postgraduates' ability to combine theories with practice. However, many problems have been found in the implementation process of the off-campus tutor system. These problems are reflected in employment procedures, employment standards, employment term, etc. Impacted by these problems, the off-campus tutor system exists in form only, which has failed to live up to its expected effect. Therefore, it is necessary to improve the content design of the off-campus tutor system for law postgraduates through the top-level design. Only in this way can the off-campus system give full play to its due role.
\end{abstract}

\section{Overview of the Off-campus Tutor System for Law Postgraduates}

\section{Concept of the Off-campus Tutor System for Law Postgraduates}

The concept of the off-campus tutor system for law postgraduates should be clarified. To the end, the concept and scope of law postgraduates should first be standardized. In China, law postgraduates include Doctor of Laws candidates, Master of Laws candidates, Juris Master (for law majors) candidates and Juris Master (for non-law majors) candidates. Doctor of Laws candidates and Master of Laws candidates both fall under the scope of academic postgraduates; while Juris Master (for law majors) candidates and Juris Master (for non-law majors) candidates are professional postgraduates. Both academic postgraduates and professional postgraduates adopt legal knowledge as their professional background. The only difference is that Doctor of Laws and Master of Laws programs pay more attention to academic research. On the contrary, JM programs attach great importance to practice. Therefore, for the convenience of discussion and research in this paper, law postgraduates of either the academic type or the professional type are both addressed as law postgraduates. In other words, all postgraduates studying law with a law learning background are all regarded as law postgraduates in this paper. In every postgraduate program, there are campus tutors assigned to provide guidance for postgraduates on academic learning, scientific research, practice and academic paper writing. In order to enhance the academic research ability or practical ability of postgraduates, the off-campus tutors with a similar academic background are employed to guide postgraduates' practice. The system of having the campus tutor and the off-campus tutor jointly supervise postgraduates' completion of their postgraduate studies is known as the "dual-tutor system". To sum up, the off-campus tutor system for law postgraduates is a system which is set up by law colleges of institutions of higher learning and employs personnel off the campus as tutors for postgraduates.

\section{Characteristics of the Off-campus Tutor System for Law Postgraduates}

The law postgraduate off-campus tutor system is a system specially designed by law colleges of institutions of higher learning. From the perspective of practice, characteristics of the off-campus tutor system for law postgraduates can be boiled down into the following aspects:

First, specificity of subjects. The off-campus tutor system, as its name implies, employs tutors outside the campus to supervise postgraduates' study. Therefore, the primary prerequisite for an off-campus tutor is that the tutor should be outside the university personnel system, meaning that personnel within the university personnel system cannot be employed as off-campus tutors. Under 
general conditions, off-campus tutors are scholars or professors with certain academic influence or those having made some achievements in practice. Law is a highly practice-oriented subject. The off-campus tutors for law postgraduates are usually personages or famous scholars in the law circles, personnel working for public security bureaus, procuratorate organs or courts, or lawyers. Only these people are qualified to be off-campus tutors for law postgraduates. Therefore, off-campus tutors for law postgraduates are limited to people with certain qualification. This demonstrates specificity of subjects for law postgraduates.

Second, specificity of development targets. From the perspective of practice, the off-campus tutor system for law postgraduates is mainly targeted at law postgraduates studying full time at school. This means that, as long as the law postgraduates, either the academic Master of Laws candidates or Doctor of Laws candidates or the professional Juris Master candidates, study at school on a full-time basis, they can receive guidance from off-campus tutors. Therefore, the off-campus tutor system for law postgraduates is only applicable to full-time postgraduates studying at school. It is not applicable to on-the-job postgraduate education.

Third, combination of the development models. The off-campus tutor system can fully capitalize on the professionalism of tutors and combine it with the traditional school education. In the joint development model, the role played by the campus tutor and the off-campus tutor is different. The two sides are both inalienable. This suggests that the off-campus tutor system for law postgraduates should be an important link of the joint postgraduate development process . In the enrolment link, the off-campus tutor must work closely with the campus tutor. Neither has the independent right to enroll students.

Fourth, practicableness of the development content. The main purpose of the law postgraduate off-campus tutor system is to make up lack of practical experience of campus tutors in providing guidance for law postgraduates. Thereby, off-campus tutors are primary responsible for developing postgraduates' practical ability. This shows the important role of off-campus tutors for law postgraduates in developing campus postgraduates' practice ability. Hence, the development content provided by off-campus tutors should be practicable.

Fifth, limit of the scope of official duties. The main duty of off-campus tutors for law postgraduates is different from that of campus postgraduates. Not only should campus tutors provide guidance for students in terms of their academic study, scientific research and paper writing, but also they are expected to offer suggestions to students in terms of their life, ideas, and psychology. On the contrary, off-campus tutors are not responsible for guiding postgraduates on life, ideology, and psychology. Their duty is limited to supervising postgraduates on academic study, scientific research, paper writing and practice.

\section{Implementation Status of the Off-campus Tutor System for Law Postgraduates}

So far, many law colleges in institutions of higher learning have drawn up corresponding development plans for their postgraduates, of which the off-campus tutor system is an important one. However, the conditions, scope of duties and development models vary in different institutions of higher learning. In 2009, the Ministry of Education of the PRC promulgated "Several Suggestions on Development of Full-time Professional Master Candidates”, which provides a series of stipulations on how to develop postgraduates pursuing professional master's degree. It also describes the scope of duties of off-campus tutors. Following that, various institutions of higher learning have also introduced their own development plans. For example, Fudan University has formulated "Methods on Selection and Management of Off-campus Part-time Tutors for Full-time Professional Degrees (Trial)"; Wuhan University has formulated "Regulations on Management of Off-campus Part-time Tutors for Postgraduates Pursuing Professional Degrees”; Heilongjiang University has formulated "Regulations on Employment of Off-campus Part-time Tutors for Practice of Postgraduates Pursuing Professional Law Degrees”. All these regulations stipulate on employment of off-campus tutors for postgraduates in great detail. Of course, there are some institutions of higher learning already introducing the off-campus tutor system for academic law degrees. For example, China University of Political Science and Law has arranged off-campus 
tutors for its doctoral candidates concerning characteristics of its Doctor of Laws programs. Nevertheless, most of them are for postgraduates pursuing professional law degrees rather than academic law degrees. The main reason behind this is academic degree postgraduate programs have a long-term development history, thus having accumulated rich development experience. In contrast, professional degree postgraduate programs mostly have a short development history, thus lacking relevant development experience. This also justifies the necessity of introducing more external forces to provide better supervision for postgraduates. On the other hand, postgraduates pursuing professional degrees are large in number. The shortage of campus tutors for professional degree programs has also prompted cooperation between campus tutors and off-campus tutors. To sum up, the off-campus tutor system is widely adopted by professional law degree programs but less adopted by academic law degree programs.

\section{Problems Existing in the Off-campus Tutor System for Law Postgraduates}

The off-campus tutor system for law postgraduates plays an important role in developing law postgraduates' practical ability. However, facts show that it still has some problems, which are mainly reflected in the following aspects:

\section{Lack of Transparency of the Employment Process}

Currently, a majority of law colleges have stipulated on employment qualifications, rights, obligations, and management methods of off-campus tutors. However, the employment procedures are usually not clarified or, even if they are pinpointed, they are not detailed enough. The most striking problem found in the process of employment is lack of transparency of employment procedures, including selection, competition, assessment, announcement and employment. There are no transparent rules on implementation of every link. This is mainly attributable to problems existing in employment of off-campus tutors. Sometimes, those who are unable to provide effective guidance for students or who do not have adequate time to guide students are chosen as off-campus tutors. This is absolutely not beneficial to development of law postgraduates.

\section{Lack of Unity of Employment Standards}

Facts show that many law colleges do not stipulate directly on employment conditions or standards of off-campus tutors. Even there are any, the stipulations are much too abstract. Take "Regulations of the Law College of Heilongjiang University on Employment of Off-campus Part-time Tutors for Practice of Postgraduates Pursuing Professional Law Degrees" for example. There are five requirements for employment of off-campus tutors. First, rigorous attitude towards academic study. Second, below 60 years old. Third, certain theoretical knowledge and practical ability, and competence for relevant duties. Fourth, master's degree or above. Fifth, practice for more than five years. Most of these conditions are "peripheral" conditions. The core content is not involved, such as standards of their theoretical and practice level. As a result, many law colleges are casual in employing off-campus tutors, and the phenomena of appointing people by favoritism are common to see.

\section{Lack of Limitations for the Term of Employment}

Theoretically, the employment system should have a limited term of employment. If off-campus tutors fail to pass assessment upon expiration of their employment term or during their employment term, the employment relationship should be terminated. However, employment of off-campus tutors has not yet been rigorous enough. In some law colleges, an off-campus tutor just supervises one postgraduate until the postgraduate graduates after three years. Only after that will the off-campus tutor continue to supervise the second postgraduate. Differently, some law colleges have an off-campus tutor guide one postgraduate every year from the moment the postgraduate is admitted. In terms of the term of employment, many law colleges do not stipulate on the term of employment. In reality, off-campus tutors in some colleges, after supervising a batch of students, will no longer continue to guide the second batch, and the phenomenon is common to find. 
Inadequate clarity of the employment term, lack of the elimination mechanism and formalism of the implementation process - all this has resulted in lack of rigorousness in the employment process of off-campus tutors.

\section{Formalism of the Supervision Process}

Law is a highly practice-oriented subject. Academic study of law is closely linked to law practice. Therefore, it is necessary to strengthen development of law postgraduates' practice ability, turning them into talents good at combining theories and practice. This is an important direction for postgraduate development and also a primary cause of employing off-campus tutors for law postgraduates. Currently, off-campus tutors are seldom fully devoted to postgraduate development. Most of them just offer guidance on academic paper writing of postgraduates. There has not yet been a detailed plan for postgraduates' practical ability development. Consequently, off-campus tutors exist in form only, and many problems have been popping up in the operation process of the off-campus tutor system for law postgraduates.

\section{Insignificant Effect of the Off-campus Tutor System}

In many law colleges, off-campus tutors have not fully displayed their role. This is mainly caused by lack of clarity about obligations and rights of off-campus tutors. Some off-campus tutors just regard their position as an honor but fully ignore their due obligations. The loose connection between off-campus tutors and postgraduates is a case in point. If off-campus tutors are responsible, they will arrange periodical meeting with postgraduates, guiding their paper writing and practice. However, most off-campus tutors are just in a position to guide postgraduates' graduation paper writing. This seriously impairs the due effect of the off-campus tutor system. A main reason for this is there have not yet been clear regulations stipulated on rights and obligations of off-campus tutors.

\section{Causes of Problems Existing in the Off-campus Tutor System for Law Postgraduates}

In Section 2, problems existing in the off-campus tutor system for law postgraduates are pointed out. In this section, causes of these problems are examined and can be boiled down in the following aspects:

\section{Lack of Unity of Standards on the Off-campus Tutor System}

Standards are a fundamental tool for employment of off-campus tutors. These standards can also help maximize the role of the off-campus tutor system. In reality, the off-campus tutor system for law postgraduates lacks a top-level design. Most law colleges regulate their off-campus tutor employment based on their own situations. As a result, these standards vary from each other in different law colleges. This is a main cause of problems existing in the current off-campus tutor system for law postgraduates.

\section{Lack of Rigorousness in Implementation}

In employing off-campus tutors, law colleges show inadequate rigorousness in the employment procedures. Under many conditions, off-campus tutors are employed upon recommendation of campus teachers. There are even no meetings held to discuss feasibility of the employment decision, let alone assess academic ability and practical ability of these candidates. Some off-campus tutors are classmates or friends of campus teachers. This gives rise to the phenomenon of appointing people by favoritism. Lack of rigorousness in practice can easily make the off-campus tutor system exist in name only. Finally, the guiding effect of off-campus tutors is undermined.

\section{Off-campus Tutors as a Tool to Win Honor and Social Status}

Many off-campus tutors regard their position as an honor, which can promote their personal reputation and social status. As mentioned above, law is a highly practice-oriented subject. The off-campus tutors selected should be those having made remarkable achievements in relevant fields. In other words, off-campus tutors should have both practical ability and theoretical knowledge. To 
be more respectable in the current society, some people might gain their qualification as the off-campus tutor through unfair competition, and this position can win more recognition for their law practice. Existence of this phenomenon might turn off-campus tutors as a tool to win fame and social status. Under the condition, the guidance effect of off-campus tutors on law postgraduates might be greatly impaired.

\section{Countermeasures for Improvement of the Off-campus Tutor System for Law Postgraduates}

Based on the above discussion and analysis, this paper thinks that the following measures can be taken to further standardize and improve the off-campus tutor system for law postgraduates.

\section{Unifying the Dual-tutor System Top-level Design}

Currently, regulations of the Ministry of Education of the PRC on the dual-tutor system have not yet been complete enough. "Several Suggestions on Development of Full-time Professional Master Candidates" promulgated in 2009 offers regulations on the off-campus tutor system, but these regulations are not applicable to academic postgraduates. After realizing this, many law colleges have also introduced off-campus tutors for academic law degree programs so as to make up the shortage of campus tutors. Therefore, the Ministry of Education of the PRC should further unify the top-level design of the dual-tutor system without distinguishing whether the postgraduate programs are academic or professional. Unified management of these two types of postgraduate programs can promote accommodation of the off-campus tutor system to practice requirements of law postgraduates. This can also bring a substantial improvement to law postgraduates' practice ability, scientific research level and paper writing quality.

\section{Strengthening Fairness of Employment Procedures}

Facts show that employment procedures of off-campus tutors for law postgraduates have not yet been standardized. Transparency is lacking particularly in selection, competition, assessment, announcement and employment of law postgraduates. In other words, employment procedures of off-campus tutors have not yet been put under comprehensive supervision of students and teachers. Concerning the phenomena, employment procedures of off-campus tutors should be further standardized in the top-level design. To be specific, resumes of candidates chosen by law colleges should first be publicized on the Internet. Students can vote for their favorite ones. Those getting the most votes can be selected as off-campus tutors. Meanwhile, the final election results should be announced. If there are no dissents about the election results during the announcement period, the candidates can be finally employed as off-campus tutors. After that, the law colleges can handle the employment procedures for the off-campus tutors. Such an employment process can increase transparency of off-campus tutors. Students' participation can, to a large extent, avoid the black-box operation. Besides, the qualifications of off-campus tutors thus elected are trusted by students, which can facilitate management of the relationship between off-campus tutors and students.

\section{Improving the Off-campus Employment Standards}

So far, there have not yet been unified standards for employment of off-campus tutors. Most standards are too general, which do not clarify requirements of off-campus tutors' core abilities. As a result, appointment of off-campus tutors is too formalistic. It is suggested that employment standards for off-campus tutors should be clarified in top-level design. In particular, the core standards should highlight assessment of off-campus tutors' research ability and practical ability. For example, there should be quantitative regulations on off-campus tutors' publication of academic achievements or number of cases handled thereby. This can provide a preliminary scope for investigation of off-campus tutors' research and practical ability and effectively avoid the phenomena of appointing off-campus tutors by favoritism.

\section{Standardizing the Assessment System within Postgraduates' Employment Term}

Regulations on the employment term and assessment of off-campus tutors for law postgraduates 
have not yet been clarified. Due to that, off-campus tutor employment process lacks a good order. Therefore, in the top-level design, more regulations should be introduced to specify the employment term and assessment of off-campus tutors. Only in this way can the off-campus tutor system be standardized. First, the employment term of off-campus tutors should be clarified. Every five years can be defined as a complete employment term. Within the term of employment, the off-campus tutor can supervise a newly-admitted law postgraduate every year. Second, the mid-term assessment for off-campus tutors is necessary. To be specific, the off-campus tutor should be fully assessed on the third year of his or her employment. The assessment is mainly organized to investigate postgraduates' academic and practical ability. Quality of academic papers written by postgraduates under the off-campus tutor's supervision should be given priority to. If postgraduates fail to write quality academic papers, it means the off-campus tutor lacks essential abilities to guide students. Such off-campus tutors should be stopped to be employed immediately. All in all, standardization of the mid-term assessment system can contribute to standardized operation of the off-campus tutor system for law postgraduates.

\section{Clarifying Quantitative Standards for Off-campus Tutors’ Performance}

As mentioned above, off-campus tutors' supervision is sometimes too formalistic. Regarding this problem, quantitative standards can be set for off-campus tutors' performance in supervising law postgraduates, such as the number of practice-oriented lectures offered for postgraduates every semester, and the number of supervisions offered to postgraduates' academic writing on a monthly basis or on an annual basis. Additionally, the minimum times of the mock court or law case study organized by off-campus tutors for law postgraduates can be stipulated. All this can prevent formalism of off-campus tutors' role in bringing up law postgraduates with practical ability.

\section{Detailing Obligations of the Off-campus Tutors}

There have not yet been detailed regulations on rights and obligations of off-campus tutors for law postgraduates. As a result, many off-campus tutors are not wholeheartedly devoted to the guidance process. Of course, there are some off-campus tutors highly responsible for law postgraduates but there are no effective incentives to guarantee sustainability of their commitment to providing all-around guidance for law postgraduates. To cope with this problem, rights and obligations of off-campus tutors should be further clarified, which is the most effective measure. For example, obligations of off-campus tutors in holding mock courts, law case study and guidance on academic writing can be further detailed. Meanwhile, off-campus tutors achieving outstanding effects in guiding law postgraduates should be rewarded. This can encourage more off-campus tutors to spend more time in supervising law postgraduates, and the overall guidance effect of off-campus tutors can be improved.

\section{Summary}

Law is a subject attaching great importance to practice. The dual-tutor system can provide guidance for law postgraduates' all-around development. It can not only benefit postgraduates' grasp of theories, but also improve postgraduates' practical ability. However, this research finds that the off-campus tutor system is mainly targeted at professional law degree programs rather than academic law degree programs. Facts also show that the role of off-campus tutors in guiding law postgraduates is uneven. Moreover, some problems have been discovered. Therefore, improvement of the off-campus tutor system has become a necessity. Through top-level design, regulations on the off-campus tutor system for academic postgraduates and professional postgraduates can be unified. Meanwhile, the employment procedures, standards, term, assessment system, guidance process and obligations and rights of off-campus tutors should be further elaborated. Only in this way can off-campus tutors give the fullest play to their role. 


\section{Reference}

[1] Chen Wei, Li Jun. The exploration and summary of the training mode of the dual tutorial system with Professional Master of Law[J]. Journal of Dali University,2016 (9): 82.

[2]Dai Jitao. Double-tutor system in the cultivation of Juris Master: Practice and perfection Taking the cooperative training as the center[J].Daqing Social Sciences, 2015 (27): 85.

[3] Gao Xuan. Reform path of the Juris Master development model[J]. Social Scientist, 2017 (4): 103.

[4] Liu Lei. Research into disproportion of the JM student-to-tutor ratio - Based on empirical survey of JM enrolment[J]. Journal of Jianghan University (Social Science Edition), 2015 (1): 109.

[5] Sun Haoliang, Tang Shi. Improvement of the dual-tutor system in development of Juris Master[J]. China Legal Education Research, 2017 (2): 43. 